BIOKEMISTRI 17(1):13-18 (June 2005)

Available online at $h t t p: / / w w w$.bioline.org. br/bk.

Abstracted online at www.ajol.info/journals/biokem

Printed in Nigeria
An international journal published by the

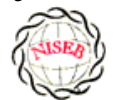

OVigerian Bociety for \&̊xperimental \&iology

\title{
Effect of repeated administration of aqueous extract of Enantia chloranta stem bark on selected enzyme activities of rat liver
}

\author{
Musbau A. AKANJI ${ }^{1}$ and Abdulfatai A. ADESOKAN ${ }^{2 *}$ \\ ${ }^{I}$ Department of Biochemistry, Faculty of Science, University of Ilorin, Ilorin, Nigeria. \\ ${ }^{2}$ Department of Physiology and Biochemistry, Faculty of Basic Medical Sciences, College \\ of Medicine, University of Ilorin, Ilorin, Nigeria.
}

Received 28 September 2004

MS/No BKM/2004/025, () 2005 Nigerian Society for Experimental Biology. All rights reserved.

\begin{abstract}
The effect of repeated administration of aqueous extract of Enantia chloranta stem bark on selected enzyme activities of rat liver was investigated. The aqueous extract of the plant was administered to white albino rats daily at $24 \mathrm{hr}$ interval at a dosage level of $100 \mathrm{mg} / \mathrm{kg}$ body weight after which the rats were sacrificed after receiving 1,3 and 5 daily oral doses. Administration of the extract produced significant reduction $(\mathrm{p}<0.05)$ in the activities of alkaline phosphatase (ALP) and lactate dehydrogenase (LDH) in the liver. There were no significant change in the activities of the serum enzymes $(p>0.05)$. There was a significant increase $(\mathrm{p}<0.05)$ in the activity of glutamate pyruvate transaminase (GPT) in the liver which was not accompanied by any significant change in the serum enzyme $(\mathrm{P}>0.05)$. However, there was no significant change in the activity of glutamate oxaloacetate transaminase (GOT) in the liver and serum $(\mathrm{P}>0.05)$. The results suggest inhibition of ALP and LDH by the plant extract while same extract resulted in induction of synthesis of GPT. The aqueous extract of Enantia chloranta stem bark has brought about alterations in the concentration of the enzymes and this may affect the functions of these enzymes.
\end{abstract}

Key words: Aqueous extract, Enantia chloranta, liver enzymes

*Author to whom all correspondence should be addressed.

E-mail: adesokan_ayoade@yahoo.com 


\section{INTRODUCTION}

The worldwide increasing demand for medicine from natural sources ${ }^{1}$ and the global Roll Back Malaria initiative that set up Medicines for Malaria Venture (MMV) to foster and accelerate research into innovative drugs with antimalaria properties ${ }^{2}$ has motivated the search for plants with potential pharmacological and therapeutic uses. Plants or various parts of the plant have been used over the ages for therapeutic purposes ${ }^{3,4,5}$ and one of such is Enantia chloranta.

Enantia chloranta [Annonaceae], (Dokita Igbo) ${ }^{4}$ is an ornamental tree of up to $30 \mathrm{~m}$ high, with dense foliage and spreading crown. The stem is fluted, the bark fissured geometrically and the outer bark is thin, dark brown while the inner bark is light brown above and pale cream beneath. The leaves are elliptic, sometimes becoming wider at the apex, $5-14 \mathrm{~cm}$ broad, arranged alternately. The leaves display up to 20 pairs of prominent lateral veins, and parallel secondary nerves. It is a component of fever preparations by traditional medicine practitioners in the forest region of Nigeria. The stem bark is widely used by many localities in Nigeria in the management of malaria without recourse to its possible deleterious effect. It is therefore imperative to ascertain the effect of the aqueous extract of the stem bark on selected liver enzymes since this organ is responsible for the detoxification of foreign substances.

The activities of alkaline phosphatase (ALP), lactate dehydrogenase (LDH), glutamate oxaloacetate transaminase (GOT) and glutamate pyruvate transaminases (GPT) are useful "marker" enzymes of damage to the liver and its hepatocytes ${ }^{6,7,8,9}$ and were assayed following the repeated administration of aqueous extract of Enantia chloranta stem bark.

\section{MATERIALS AND METHODS}

\section{Materials}

Stem bark of Enantia chloranta obtained from the forest at Ore, Nigeria, was identified at the Department of Biological Sciences, University of Ilorin, Ilorin, Nigeria where voucher specimen was deposited in the Departmental Herbarium. p - Nitro phenyl phosphate (disodium salt) was obtained from British Drug Houses (Chemicals) Limited, Pooles, United Kingdom. Assay kit for lactate dehydrogenase was obtained from Quimica Clinica Aplicada, Amposta, Spain, while those for the transaminases were obtained from Randox laboratories, Ltd, United Kingdom. All other reagents used were of analytical grade and were prepared in all glass distilled water.

White albino rats (Rattus novergicus) weighing in the average of $200 \mathrm{~g} \pm 18.5$ were obtained from the Small Animal Holding Unit of the Department of Biochemistry, University of Ilorin, Ilorin, Nigeria. The animals were housed in clean metabolic cages and exposed to $12 \mathrm{hrs}$ of light and $12 \mathrm{hrs}$ of darkness at room temperature between 28 to $32^{\circ} \mathrm{C}$ and relative humidity of 50$55 \%$. The animals were maintained on rat pellets (Bendel Feeds and Flour Mill, Owu, Edo State, Nigeria) and water ad libitum.

\section{Preparation of plant extract}

Samples of stem bark of the plant were sun dried for 7 days, ground into powder and stored in a sealed plastic container until required. $10 \mathrm{~g}$ of the powder was extracted in $100 \mathrm{mls}$ of tap water. This was stirred with magnetic stirrer for $1 \mathrm{hr}$ and allowed to settle for $24 \mathrm{hr}$. It was then filtered through muslin cloth and the filtrate obtained was evaporated to dryness. The aqueous extract was then made by preparing $2 \%$ using tap water to give a required dosage of $100 \mathrm{mg} / \mathrm{kg}$ body weight ${ }^{10}$.

\section{Administration of extract}

The rats were allowed to acclimatize for two weeks before the commencement of the experiment. They were randomly divided into 5 groups with each group consisting of 5 rats. Group 1 which served as the control was orally administered with $1 \mathrm{ml}$ of tap water once daily at 24hrs intervals for 5days. Groups 2, 3 and 4 were orally administered with $1 \mathrm{ml}$ of the extract to give the required dose of $100 \mathrm{mg} / \mathrm{kg}$ body weight and were sacrificed $24 \mathrm{~h}$ after receiving 1 , 3 and 5 daily doses of the extract while those in group 1 were sacrificed $24 \mathrm{~h}$ after receiving their 5 daily doses 9 . Those in group 5 were treated in the same way like those in group 4 except that they were left untreated for additional 5days before being sacrificed to evaluate for possible 
recovery effect by the animals. The 5days period was to simulate the number of days the plant is being used locally for the management of malaria fever. All the animals were thereafter maintained on rat pellet and tap water ad libitum after their daily administration done between 0900-1000hrs.

\section{Preparation of serum and liver homogenates}

The neck area of the rats which were cleared of fur and skin to expose the jugular veins were cut with sterile scalpel blade under diethyl ether anesthesia. Blood was collected into clean dry beakers and allowed to clot at room temperature for $1 \mathrm{hr}$. It was then refrigerated for another 45 minutes ${ }^{11}$. The clear serum was collected with Pasteur pipette and kept frozen until required, usually not more than $12 \mathrm{hrs}$. The animals were thereafter quickly dissected and the liver removed into ice-cold $0.25 \mathrm{M}$ sucrose solution. It was then blotted with tissue paper and homogenized in ice-cold $0.25 \mathrm{M}$ sucrose solution $(1: 5 \mathrm{w} / \mathrm{v})$ using Teflon homogenizer. This was kept frozen until required $^{8}$ for the enzyme assay.

\section{Determination of protein and enzyme activities}

Lactate dehydrogenase (EC 1.1.1.26) activity was determined by the method as described by Wroblewski and La Due ${ }^{12}$. Alkaline phosphatase (EC 3.1.3.1) activity was assayed using the method described by Wright $e t$ $a l^{13}$. Glutamate oxaloacetate transaminase (EC 2.6.1.1) and Glutamate pyruvate transaminase (EC 2.6.1.2) activities were assayed using the methods described by Mohun and Cook $^{14}$. Protein concentration was determined by the Biuret method as described by Plummer ${ }^{15}$.

\section{Statistical analysis}

Data were subjected to one way Analysis of Variance to account for the various groups and complemented with Student's ttest $^{16}$. Statistical significance was taken at $\mathrm{P}<0.05$.

\section{RESULTS}

Tables 1 and 2 shows the effect of administration of aqueous extract of Enantia chloranta stem bark on selected liver and serum enzymes respectively. There was a significant reduction in liver alkaline phosphatase activity following the administration of aqueous extract of Enantia chloranta stem bark $(\mathrm{P}<0.05)$. The reduction was noticeable from after the first dose and it persisted throughout the duration of experiment. This pattern of reduction in ALP activity was maintained even after the administration had been terminated and the rats left for another 5days (Table 1). For lactate dehydrogenase activity, the reduction in enzyme activity was not significant until after the fifth dose of extract administration $(\mathrm{P}<0.05)$. This pattern of reduction of about 1/5th the control also extended to the animals in group 5 $(\mathrm{P}<0.05)$.The administration of the extract resulted in significant increase in the activity of Glutamate pyruvate transaminase only after the first daily dose and this pattern of increase was also the case in group $5 \quad(\mathrm{P}<0.05)$. Administration of the extract to all the various groups of the animals did not produce any significant effect on the activity of rat liver glutamate oxaloacetate transaminase $(\mathrm{p}>0.05)$. There was also no significant change in all the serum enzymes investigated throughout the duration of the experiment (Table 2).

\section{DISCUSSION}

Measurement of the activities of various enzymes in tissues and body fluids play a significant and well-known aid in disease investigation and diagnosis ${ }^{17}$. Tissue enzyme assay can also indicate tissue cellular damage long before structural damage is revealed by some other conventional techniques ${ }^{18}$.

Alkaline phosphatase is a 'marker' enzyme for the plasma membrane and endoplasmic reticulum ${ }^{7}$. It is often employed to assess the integrity of the plasma membrane? Reduction in the activities of liver alkaline phosphatase immediately after the first dose of extract implied either gradual labilization of the plasma membrane of the liver cells ${ }^{9,19}$ or inactivation of the enzyme molecule ${ }^{20}$. However, since there was no significant change in the levels of serum ALP (Table 2), the reduction in the liver ALP activity could therefore be attributed to enzyme inactivation rather than labilization of the 
Table 1: Selected liver enzyme activities following daily administration of aqueous extract of Enantia chloranta stem

\begin{tabular}{|c|c|c|c|c|}
\hline \multicolumn{5}{|c|}{ Specific enzyme activities (nM/min/mg protein) } \\
\hline Days & $\begin{array}{l}\text { Alkaline } \\
\text { Phosphatase }\end{array}$ & $\begin{array}{l}\text { Lactate } \\
\text { Dehydrogenase }\end{array}$ & $\begin{array}{l}\text { Glutamate } \\
\text { Pyruvate } \\
\text { Transaminase }\end{array}$ & $\begin{array}{l}\text { Glutamate } \\
\text { Oxaloacetate } \\
\text { Transaminase }\end{array}$ \\
\hline 0 & $2.85 \pm 0.99$ & $1.87 \pm 0.43$ & $38.15 \pm 5.68$ & $160.01 \pm 28.60$ \\
\hline 1 & $0.55 \pm 0.06 *$ & $1.84 \pm 0.88$ & $39.10 \pm 4.62$ & $159.55 \pm 30.36$ \\
\hline 3 & $0.79 \pm 0.07 *$ & $1.85 \pm 0.61$ & $64.72 \pm 6.39 *$ & $163.77 \pm 18.67$ \\
\hline 5 & $0.53 \pm 0.08 *$ & $0.50 \pm 0.07 *$ & $61.13 \pm 4.80 *$ & $165.47 \pm 20.82$ \\
\hline+5 & $0.56 \pm 0.05 *$ & $0.38 \pm 0.09 *$ & $69.23 \pm 2.92 *$ & $160.56 \pm 25.95$ \\
\hline
\end{tabular}

Table 2: Selected serum enzyme activities following daily administration of aqueous extract of Enantia chloranta stem

Specific enzyme activities (nM/min/mg protein)

\begin{tabular}{|c|c|c|c|c|}
\hline Days & $\begin{array}{l}\text { Alkaline } \\
\text { Phosphatase }\end{array}$ & $\begin{array}{l}\text { Lactate } \\
\text { Dehydrogenase }\end{array}$ & $\begin{array}{l}\text { Glutamate } \\
\text { Pyruvate } \\
\text { Transaminase }\end{array}$ & $\begin{array}{l}\text { Glutamate } \\
\text { Oxaloacetate } \\
\text { Transaminase }\end{array}$ \\
\hline 0 & $0.25 \pm 0.09$ & $0.87 \pm 0.03$ & $0.77 \pm 0.02$ & $0.71 \pm 0.05$ \\
\hline 1 & $0.25 \pm 0.05$ & $0.84 \pm 0.08$ & $0.76 \pm 0.02$ & $0.75 \pm 0.03$ \\
\hline 3 & $0.23 \pm 0.07$ & $0.85 \pm 0.04$ & $0.75 \pm 0.04$ & $0.72 \pm 0.01$ \\
\hline 5 & $0.23 \pm 0.06$ & $0.86 \pm 0.05$ & $0.73 \pm 0.08$ & $0.70 \pm 0.05$ \\
\hline+5 & $0.25 \pm 0.07$ & $0.88 \pm 0.06$ & $0.74 \pm 0.04$ & $0.68 \pm 0.05$ \\
\hline
\end{tabular}

+5 indicate that rats in this group were administered daily doses of the extract for 5 days and left for additional 5 days without any administration. Results are mean of 8 replicates \pm SEM. Values are not significantly different from their control $(P<0.05)$. 
plasma membrane of the hepatocyte. Reduction in ALP activity will adversely affect the adequate transportation of the required ions/molecules across the cell membrane ${ }^{9}$.

The reduction in the activity of liver $\mathrm{LDH}$, a cytosolic enzyme ${ }^{12}$, without corresponding increase in the serum enzyme (Table 2) may also be adduced to inhibition of the enzyme activity at the cellular level. Such a reduction may have consequential effect on the glycolytic pathway. Glutamate pyruvate transaminase, a more liverspecific enzyme of damage than glutamate oxaloacetate transaminase ${ }^{21}$ increased significantly in the liver (Table 1) without corresponding increase in the serum (Table 2). This is probably as a result of induction of enzyme synthesis due to defence reaction by the organ to the exogenous substance or loss of other proteins ${ }^{9,11}$. This trend may have consequential effect on amino acid metabolism ${ }^{22}$.

In conclusion, the administration of the aqueous extract of Enantia chloranta to rats has resulted in inactivation/inhibition of alkaline phosphatase and lactate dehydrogenase. It has also caused induction of glutamate pyruvate transaminase. These alterations will adversely affect the functions of the liver enzymes investigated.

\section{REFERENCES}

1. Lapa, J.A. (1992) Validacao De Plants Medicinae da medicine traditional. Reunion Annual Ripronamed/Quimica Fiva Farmaceutical/ LYTED D Asuncion, Paraguay, August, 23:27- 1992

2. World Health Organisation (2001) A World Health Organisation Bulletin on Roll Back Malaria Initiative.

3. Lambo, J.O. (1979) 'The Healing powers of herbs with special reference to obstetrics and gynaecology' African Medicinal plants (ed Sofowora E A). University of Ife Press Ife, Nigeria Pp. 23

4. Iwu, M.M. (1993) In: Handbook of African Medicinal plants. CRC Press, LL.C. USA. Pp.113

5. Sofowora, E.A. (1993) In: Medicinal plants and Traditional Medicine in Africa. ( $\left.2^{\text {nd }} \mathrm{ed}\right)$, Spectrum Books Limited. Pp 26:30.
6. Chapatwala., K., Boykin, M.A and Rajanna, B (1982) Effect of intraperitoneally injected cadmium on renal and glycogenic enzymes in the rats. Drug \& Chemical Toxicol. 5: 305-317.

7. Wright, P.J and Plummer, D. T (1974) The use of urinary enzyme measurement to detect renal changes caused by nephrotoxic compounds. Biochem \& Pharmacol. 12: 65

8. Ngaha, E.O. (1982) Further studies on the in vivo effect of cephalondine on the sterility of rat kidney lysosomes. Biochem. Pharmacol. 3:1843-1847.

9. Akanji, M.A., Olagoke, O.A. and Oloyede, O.B. (1993) Effect of chronic consumption of metabisulphite on the integrity of the rat kidney cellular system. Toxicol. 81: 173-179.

10. Adesokan, A.A. (2004) Effect of administration of aqueous extract of Enantia chloranta on some enzyme activities of selected rat tissues. M.Sc. Thesis, University of Ilorin, Ilorin, Nigeria

11. Akanji, M.A.and Ngaha, E.O. (1989) Effect of repeated administration of berenil on urinary excretion with corresponding tissue pattern in rats Pharmacol. \& Toxicol. 64: 272

12. Wroblewski, F. and La Due, J.S. (1955) Lactate dehydrogenase activity in blood Proc. Soc. Exp. Biol. Med. 90: 210.

13. Wright, P.J., Leathwood, P.D. and Plummer, D.T. (1972) Enzymes in rat urine: Alkaline phosphatase. Enzymologia 42: 459 462.

14. Mohun, A.F.and Cook, L.J. (1957) Simple method of measuring serum levels of glutamate oxaloacetate and glutamate pyruvate transaminases. J. Clin. Pathol. 10:394-399.

15. Plummer, D.T. (1978) An introduction to Practical Biochemistry ( $2^{\text {nd }}$ ed) Mc. Graw Hill, London. Pp. 144:145.

16. Dixon, W.J. and Massey, F.J. (1969). Introduction to Statistical Analysis, $3^{\text {rd }}$ ed. McGraw-Hill, New York

17. Malomo, S. O. (2000) Toxicological implications of ceftriaxone administration in rats. Nig. J. Biochem. Mol. Biol. 15: 33-38.

18. Akanji, M.A. (1986) A comparative biochemical study of the interaction of some 
trypanocides with rat tissue cellular system. Ph.D thesis, University of Ife, Ile-Ife.

19. Kaplan, M. M. (1972) Alkaline phosphatase. New England Journal of Medicine 286: 200-203.

20 Umezewa, H.and Hooper, I.R. (1983) Aminoglycoside antibiotic. Springer Velag Berlin, Hadelberg. New York.
21. Tietz, N.W. (1987) Fundamentals of clinical chemistry. $3^{\text {rd }}$ Edition, W.B. Saunder Company, Philadelphia

22. Jimoh, F. O. and Odutuga, A. A. (2001) Changes in the activities of some diagnostic enzymes in some rat tissues following the consumption of thermally oxidized groundnut oil. Nig. J. Biochem \& Mol. Biol. 16: 173-176. 